\title{
Personnel trends in a globalised world
}

\author{
Jana Pechová ${ }^{1, *}$ \\ 1ŠKODA AUTO University, ŠAVŠ, Na Karmeli 1457, 29301 Mladá Boleslav, Czech republic
}

\begin{abstract}
The labour market is the main external condition for personnel management and is influenced by population development, immigration policy of the state, globalization of the labour market and trends in the content of work activities. Human resources as grown in importance and value in the third millennium. Transforming human capital is a fundamental factor in the success of business in global markets. The development of economics leads to an increasing need for adaptability and flexibility of workers, a creative approach and, last but not least, the ability to acquire, choose, and retain talented workers from all over the world. Personnel trends in a globalised world is oriented towards a modern method of selection or development of workers with an emphasis on the criterion of creativity. The contribution represents the usual course of VAC with the standard criteria and offers a new VAC design in relation to the key competency of the 21 st century which is creativity. The practical part of the contribution is a case study conducted qualitative research with representatives of Generation $\mathrm{X}$ and $\mathrm{Y}$ and respects the stated objective: to create a new VAC design with the selection or development criterion of creativity.
\end{abstract}

\section{Introduction}

Digital technologies will create additional cross-border opportunities for businesses. Many companies today have a global ambition at the moment of their founding and they intend to reach not only customers but also collaborators using information technology worldwide.

The globalised world brings new possibilities. People travel, work, study, live in different countries. They communicate with each other on the Web, share their ideas, culture and experience, and it is this exchange that stimulates creativity and accelerates innovation. International companies work with creative people, learn and innovate quickly and stay competitive.

\section{Virtual assessment centre}

The virtual assessment centre is the special method in a globalised world for new employee recruitment or for the short list of the management candidates or current employees. The

\footnotetext{
* Corresponding author: jana.pechova@savs.cz
} 
virtual assessment centre is a complex and flexible product for high quality recruitment and development of present employees $[6,7]$.

\subsection{Structure of VAC}

The structure of the virtual assessment centre may vary depending on the type of work recruited by each company. In the following text you can find the most common structure of the virtual assessment centre.

\section{Knowledge tests}

The Virtual Assessment Centre allows to determine the necessary knowledge for this job, soft skills, candidate's knowledge of the company.

\section{Psychological test}

Another possible method which is used at the Virtual Assessment Centre is psychological testing, it can use a traditional, $t$ test or an interpersonal questionnaire. This method is often used in stressed jobs or by the state.

The business essay and text analysis

The business essay is closed to case studies, but it is the not such a detailed assignment. The candidate must solve a real situation with the lower structure from the practise.

\section{The solution of the dilemma}

The solution of the dilemma is a situation, where the candidate solves an individual difficult situation, which is usually connected with practise.

\section{Dialog simulator}

The dialog simulator tests individual communication skills and the ability to express oneself in a specific situation.

\section{Group simulation of a real situation}

A group simulation of a real situation is used also by the classic assessment centre and it solves a real situation through the interaction of candidates. The virtual assessment centre uses group simulation of a real situation in a new way.

\section{Personal interview}

The personal interview can be personal or on-line (for example Skype, Lync) $[6,7]$.

\subsection{Criteria of VAC}

We discuss the virtual assessment centre with a company called ADDA Consultants; they offer a special interactive virtual assessment centre: PINSIGHT. It is a tool for the selection and development of managers and talents. They have offered this tool for four years. The company contacts the candidates two days before the realization with the basic information. The candidates have to have their own computer, webcam, microphone and internet. The virtual assessment centre is offered only in Czech, Slovak, English and Spanish. This AC takes three hours; the time is divided into tasks for the candidate. The first step is a document study about a fictitious company, where the candidate works as a manager [6].

The criteria which are observed during the virtual assessment centre, they are mentioned in following Table 1. 
Table 1. Criteria and their description [7].

\begin{tabular}{|c|c|}
\hline Criteria & Description \\
\hline $\begin{array}{l}\text { Sharing of the } \\
\text { vision }\end{array}$ & Convincing others to share the vision of the organisation. \\
\hline Influence & $\begin{array}{c}\text { Influencing thinking or behavior of others by revealing problems } \\
\text { hidden under surface. }\end{array}$ \\
\hline $\begin{array}{l}\text { Resistance of } \\
\text { individuals }\end{array}$ & $\begin{array}{l}\text { Resistance of individuals. Elimination of resistance towards change } \\
\text { by addressing individual fears, followed by actions. }\end{array}$ \\
\hline Innovation & Submitting creative solution of important business problems. \\
\hline Urgency & Setting ambitious objectives and creating pressure to reach them. \\
\hline Priority setting & $\begin{array}{c}\text { Identification of the most important tasks and time frame to fulfill } \\
\text { them. }\end{array}$ \\
\hline $\begin{array}{l}\text { Organisation and } \\
\text { planning }\end{array}$ & $\begin{array}{l}\text { Definition of resources to fulfill objectives, planning of individual } \\
\text { tasks with a timeframe. }\end{array}$ \\
\hline $\begin{array}{l}\text { Customer } \\
\text { orientation }\end{array}$ & Decision based on customer orientation. \\
\hline Team development & $\begin{array}{c}\text { Developing skills important for fulfillment of company objectives } \\
\text { based on definition of weaknesses. }\end{array}$ \\
\hline $\begin{array}{l}\text { Coaching and } \\
\text { mentoring }\end{array}$ & $\begin{array}{c}\text { Proactive development of others by feedback, difficult tasks, self- } \\
\text { reflexion and proposals. }\end{array}$ \\
\hline $\begin{array}{l}\text { Clear } \\
\text { communication }\end{array}$ & Definition of key thoughts only in a short and structured way. \\
\hline $\begin{array}{l}\text { Charismatic } \\
\text { communication }\end{array}$ & $\begin{array}{l}\text { Storytelling, use of metaphors and comparisons for passionate } \\
\text { communication. }\end{array}$ \\
\hline Delegation & $\begin{array}{l}\text { Delegation of projects with a clear start and end, based on skills and } \\
\text { employee interests. }\end{array}$ \\
\hline Empowerment & Empowerment along with support and responsibility. \\
\hline Showing the interest & Showing honest interest for others. \\
\hline Active listening & $\begin{array}{c}\text { Active listening and understanding followed by questions to gain } \\
\text { insight. }\end{array}$ \\
\hline $\begin{array}{l}\text { Information } \\
\text { analysis }\end{array}$ & Collection and combination of different information. \\
\hline Problem solving & Evaluation of several solutions based on clear criteria. \\
\hline Accept decisions & $\begin{array}{l}\text { Understanding a problem in its depth, decisions that address the } \\
\text { needs of all parties involved. }\end{array}$ \\
\hline
\end{tabular}




\section{Creativity}

Creativity is referred to as the ability to think independently and behave freely in order to achieve innovation and original thinking in personal, professional and social life. Creativity and innovation should be promoted from the perspective of lifelong learning.

To explain the concept of innovation, the European Commission uses the definition that innovation is the renewal and expansion of the range of products and services and related markets, the creation of new methods of production, supply and distribution, the introduction of management changes, work organization, working conditions and skills. Innovation is more than just an idea or an idea; Initiative thinking and creativity are important preconditions for innovation. Creativity is the ability to come up with new ideas, the ability of an individual to create and develop new ideas [8].

\subsection{Creative product}

Creative activity, creation and creative work is always required to see an observable outcome - a product that should above all be new, unique, progressive, valuable, useful, truthful and communicable.

Based on the level of creativity in human activity products, two types of creative products are distinguished:

1. Objective creative product - due to its objectivity it has a social significance and moves the development in the given area forward. It is a creative product that did not exist before (discovery, invention).

2. Subjective creative product - it has no social significance, it does not contribute to the development of society by new original creations, but it is of immense importance for the development of personality. Subjective products are created by individuals in problem solving, learning, playing, etc [8].

Their products are new to themselves and enrich their learning and cognition process.

The result of creative activity is characterized by novelty (innovations), originality, usefulness, recognition of the value of the product and various terms are used for it: invention (for technical or musical production), idea, idea (for science and knowledge), creation (as materialized, tangible result of creative activity), creative product, work, creations, effect, etc.

\subsection{Creative personality}

Given the complexity of the issue of creativity, it is also quite complicated to develop a system of criteria according to which one can clearly identify a creative individual from a "non-creative" one. Based on long-term observations of creative people, analysis of their works and performances, it is possible to deduce certain characteristics common to creative people.

Every person or child has talents for creativity. They need to be able to detect and develop them. Creative abilities are an innate disposition for creative activity, developed and cultivated throughout life. Most authors currently agree on six basic prerequisites for creative activity:

1. Fluency - the ability to quickly produce a wealth of ideas, richness of ideas and ideas. It is a readiness to recall words and concepts, hence the fluency of verbal, association, thought and expression.

2. Flexibility - involves the disposition to create diverse solutions to tasks, to find a variety of approaches to solving the situation, to overcome common, stereotyped solutions, whether spontaneously or based on external stimulus. 
3. Originality - the ability to see a given reality unconventionally and newly, from an extraordinary individual perspective on the situation and phenomena, the ability to find a new, strange, atypical, paradoxical solution that is beyond the limits of conventional thinking.

4. Redefinition - transformational abilities based on changing meaning or reorganization of information, ability to organize elements of complex problems into new relationships and combinations, define problems differently than before and see new purpose.

5. Sensitivity - sensitivity to problems, ability to recognize and identify potential problems and future opportunities in a timely manner, identify main pages, details and partial problems in confusing situations, orientate in poorly structured problems.

6. Elaboration - the ability to develop solutions into interesting details, rework ideas, ideas into details, new structures based on knowledge and skills, combine them in different ways, think through all the context and implications of the solution and prepare a detailed implementation process [8].

\section{Methods}

The creative task was assigned in October 2017 to 31 students of the fourth year of the master's study of combined form of SAVŠ, representatives of generation X $[2,3,4,14]$. Furthermore, in April 2019 a group of 23 students of the fourth year of full-time study of ŠAVŠ, representatives of generation Y $[2,3,4,14]$ were evaluated by six academics from the Department of Informatics, Human Resources Management and Marketing and Management ŠAVŠ. The evaluation was also attended by the personnel manager ŠAVŠ. Individual criteria were scored. The scoring scale was $0-10$ points, where 0 points meant that the criterion was not fulfilled, while the fully fulfilled criterion scored ten points. The committee was acquainted with the individual criteria a week before the evaluation, on 23.4. 2019. The task was evaluated in the form of criteria such as the novelty of the product, its originality, and the presence of the characteristics of the creative personality mentioned in Chapter 2.2. Feedback (evaluation results) received on 23.5. 2019. Individual visually presented visions are internal material of ŠAVŠ.

For the task assigned to the students, the following objectives were pursued:

- Determine whether the task is applicable to the new VAC design.

- Determine whether the task will provide an opportunity to evaluate the submitted criteria in Chap. 2.2

- Evaluate the task using the submitted criteria.

- Determine which additional criteria (Table 1) can be further evaluated within the VAC.

\subsection{Task assignment}

The task was based on theoretical background and motivational introduction, which contained the reason for the existence of the vision, its definition and characteristics. The practical part of the assignment in individual steps followed and the presentation of the output criteria followed. Further information was not given, students had free space for their own image processing of the future. The practical part of the assignment was as follows:

1. Introduce yourself, accompany your performance with a motto, picture or symbol (metaphor)

2. Introduce your personal work vision 
3. Describe briefly your status quo based on example personal SWOT / present analysis to create the future

4. What was inspiring for me in the seminar and what value (information, knowledge, skills, attitudes) did it bring me? (the question can be reformulated and based on specific work experience, foreign residence, etc.)

5. How can I use this in my practice?

6. What do I plan in my working future? How do I fulfill my vision? What will be my new "strategy" (development, education, career)?

The presentation itself should be brief, up to 7 - 10 charters, accompanied by verbal commentary, written appendices and graphic supplements. The whole presentation can follow the motto "Multum non multa" - many not many. For presentation use eg web camera, it is necessary that during presentation you can see yourself. The assessment criteria will relate to the creative product (eg Power point presentation) and the characteristics of the creative personality (your own image). The presentation should be submitted to the AIS [13].

\subsection{Results}

The evaluation results are shown in Table 2, which contains the $\mathrm{X}$ and $\mathrm{Y}$ generation resolution, the highest, the lowest and the average number of points achieved and the best and the worst-rated criteria. Out of 31 representatives of the $\mathrm{X}$ generation, 29 students presented. Out of 23 students of the Y generation, they virtually presented students with 19 . They refused, completed their studies or requested their postponement.

Table 2. Evaluation results.

\begin{tabular}{|l|c|c|c|c|c|}
\hline \multicolumn{1}{|c|}{$\begin{array}{c}\text { Generation/Evaluation } \\
\text { results }\end{array}$} & $\begin{array}{c}\text { highest } \\
\text { score }\end{array}$ & $\begin{array}{c}\text { the lowest } \\
\text { number of } \\
\text { points }\end{array}$ & $\begin{array}{c}\text { average } \\
\text { number of } \\
\text { points }\end{array}$ & $\begin{array}{c}\text { the best } \\
\text { rated } \\
\text { criterion }\end{array}$ & $\begin{array}{c}\text { the worst } \\
\text { rated } \\
\text { criterion }\end{array}$ \\
\hline $\begin{array}{l}\text { Generation X (born } \\
\text { between 1965-1980) }\end{array}$ & 297 & 32 & 195,72 & sensitivity & flexibility \\
\hline $\begin{array}{l}\text { Generation Y (born } \\
\text { between 1981-1995) }\end{array}$ & 335 & 32 & 239,37 & originality & elaboration \\
\hline
\end{tabular}

It can be stated that the objectives defined in Chap. 3.1 have been fulfilled. The task can be realized within the VAC, criteria such as fluency, flexibility, originality, redefinition, sensitivity and elaboration were measurable and besides these criteria it is also possible to assess other criteria such as sharing a vision, resistance of individuals, urgency, priority setting clear or charismatic communication. Students submitted materials created either in a power point, flipchart or on a whiteboard and presented directly in front of a web camera or a camera on mobile devices. The files were bulky - more than $5 \mathrm{MiB}$, ie a higher quota than allowed by the AIS handing room, so the students chose www.úschovna.cz as the way of handing them in and submitted a "written only" presentation to the AIS. Written and spoken presentations contained characteristics of creative products and were presented by creative personalities (20 students of generation X and 14 students of generation Y received more than 240 points in total, the maximum possible number was 360 points). The presentation featured various mind maps, original time schedules, opening doors or even a nascent Iron man. Another interesting aspect was also the environment that the students chose for their presentation - on the street, in the car, classroom or at their favorite place. From the presented work visions it is possible to evaluate individual criteria and pre-select the right people for the right place. 


\section{Conclusion}

This paper presents personal trends in today's globalised world, specifically focusing on the virtual assessment center and increasingly needed competence in the globalized world, which is creativity. At the same time, it presents a specific task in the form of a working vision to the HR personnel, on the basis of which it is possible to assess various characteristics of the creative personality and other criteria evaluated in VAC.

\section{References}

1. D. Cropley. Promoting creativity and innovation in engineering education. Psychology of Aesthetics, Creativity, and the Arts, 9(2), 161-171 (2005)

2. E. Jaderná, J. Přikrylová, D. Apková (2017). Perception of green solutions by generation Y. In Marketing Identity, Trnava. University of Ss. Cyril and Methodius in (2017)

3. E. Velinov, Diversity Management Globalization in Central and Eastern Europe: The Case of Pharmaceutical Industry. European Research Studies Journal, 21(1), 82-89 (2018)

4. E. Velinov, Diversity Management Practices in the US Tech Companies. International scientific conference Hradec Economic Days (2019)

5. H. Mohamed Hatamleh. Uprising of Creation in Education. Journal of Education and Practice, 6(14), 114-128 (2015)

6. J. Pechová, V. Šíšová, Assessment centrum: moderni nástroje výběru zaměstnanců. 1. vyd. (Praha: Management Press, 2016)

7. J. Pechová, V. Šíšová.Virtual assessment centre. In The 10th International Days of Statistics and Economics. Conference Proceedings. Praha, Czech Republic: VŠE (2016)

8. K. Chadt, L. Kouřil, J. Pechová, Art of Creativity. (Praha: UJAK, 2009)

9. M. Černe, S. Batistič, R. Kenda. HR systems, attachment styles with leaders, and the creativity-innovation nexus. Human Resource Management Review, 28(3), 271-288 (2018)

10. R. Dino n. Crossing boundaries: Toward integrating creativity, innovation, and entrepreneurship research through practice. Psychology of Aesthetics, Creativity, and the Arts, 9(2), 139-146 (2008)

11. R. Dolzhenko, S. Ginieva, Use of HR professional communities in developing the system of professional qualifications. In The 11th International Days of Statistics and Economics. Conference Proceedings. Praha, Czech Republic: VŠE, 313-323 (2017)

12. R. L. Tung, New Perspectives on Human Resource Management in a Global Context. Journal of World Business, 51(1) (2006)

13. Škoda Auto University.ŠAVŠ. Internal materials (2017, 2018, 2019).

14. T. Kincl, P. Štrach, Gender Differences in Online Customer Satisfaction: The Asymmetric and Nonlinear Effect. Services Marketing Quarterly, 39, 3, 157-174 (2017)

15. V. Del-Corte-Lora, T. Vallet-Bellmut, F. Molina-Morales. How network position interacts with the relation between creativity and innovation in clustered firms. European Planning Studies, 25(4), 561-582 (2017) 